\title{
UNJUK KERJA TURBIN CROSS-FLOW DENGAN SIMULASI CFD PADA NOSEL DAN MANUFAKTUR PADA RUNNER
}

\section{Steven Darmawan ${ }^{1}$, Abrar Riza ${ }^{1}$, M. Sobron Yamin Lubis ${ }^{1}$, Stevanus Aditya Winardi ${ }^{1}$, Reuben Christianto ${ }^{1}$}

\author{
${ }^{1}$ Program Studi Teknik Meesin, Universitas Tarumanagara Jakarta \\ Email: stevend@ft.untar.ac.id \\ Email:abrarr@ft.untar.ac.id \\ Email: sobronl@ft.untar.ac.id \\ Email: stevanusadit9@gmail.com \\ Email: christianto96@gmail.com
}

Masuk: 21-05-2021, revisi: 21-09-2021, diterima untuk diterbitkan: 06-10-2021

\begin{abstract}
ABSTRAK
Pandemi Covid-19 mengakibatkan disrupsi pada sektor energi, dimana konsumsi energi baru dan terbarukan mengalami kenaikan. Fenomena ini menunjukkan bahwa energi terbarukan menjanjikan untuk terus dikembangkan. Sesuai dengan goal ke-7 dari SDG's oleh PBB, turbin cross-flow merupakan turbin radial yang menghasilkan daya melalui konversi energi hidrolik dari air sebagai sumber energi terbarukan, menjadi energi mekanis pada poros melalui penggunaan nosel dan runner, banyak digunakan karena beberapa kelebihannya, antara lain konstruksi yang sederhana dan simetris hanya memerlukan biaya perawatan yang rendah dan sederhana serta dapat digunakan pada rentang beban yang cukup besar. Namun demikian, turbin cross-flow secara umum memiliki nilai efisiensi yang lebih rendah. Efisiensi sistem dapat ditingkatkan dengan penggunaan material runner yang seusai. Penelitian ini bertujuan untuk melakukan perancangan terhadap nosel dan proses manufaktur runner cross-flow sehingga dapat diperoleh geometri nosel serta jenis material dan proses manufaktur runner yang sesuai untuk rentang operasi, yaitu aliran air 1 fasa dengan debit 1,4 L/s. Pengembangan nosel dilakukan dengan menggunakan metode CFD pada 3 model geometri. Pengembangan terhadap runner meliputi simulasi CAM dan manufaktur pada 2 jenis material, yaitu SS 304 dan Aluminium 6061. Hasil simulasi CFD 3D menunjukkan bahwa nosel model 3 dengan dimensi panjang total 400mm, lebar $124 \mathrm{~mm}$, dan radius pada throat $75 \mathrm{~mm}$ menghasilkan kecepatan pada sisi outlet sebesar $0,135 \mathrm{~m} / \mathrm{s}$. Hasil simulasi CAM dan Manufaktur terhadap runner serta eksperimen terhadap sistem dengan nosel model 3 menunjukkan bahwa bahwa runner dengan material SS 304 menghasilkan daya, yaitu 8.38 Watt, 100\% lebih besar dibandingkan dengan runner dengan material Aluminium 6061.
\end{abstract}

Kata Kunci: Energi terarukan; Turbin cross-flow; CFD; CAM

\section{ABSTRACT}

Covid-19 pandemic has lead disruption in energy sector, new-and-renewable energy demand is increasing, which show that renewable energy is promisable to be developed. As one of the hydraulic turbine, the crossflow turbine is prospective primve mover in line with the $7^{\text {th }}$ goal of the SDG's Goals. Cross-flow turbine is radial atmospheric turbine which generates power by converting hydraulic energy from water to mechanical energy on the shaft by using nozzle and runner. The advantages make this device is became famous, including simple construction and geometry, low maintenance \& cost and can be used at wide range operation scheme. However, the cross-flow turbine system is also known to have low efficiency. Based on this condition, this research is aims to improve the efficiency with design the nozzle and to manufacture the runner with two material. The operating condition is set to 1 phase water as working fluid with $1,4 \mathrm{~L} / \mathrm{s}$ of flow. Nozzle design conducted with CFD 3D simulation from 3 different model. Runner manufacturing is conducted numerically with CAM simulation and experimentally by using CNC machining with Stainless Stell 304 and Aluminium 6061. CFD simulation on the nozzle shows that nozzle model 3 with total length of $400 \mathrm{~mm}$, width $124 \mathrm{~mm}$ and throat radius $75 \mathrm{~mm}$.resulting the maximum outlet velocity to the runner $0,135 \mathrm{~m} / \mathrm{s}$. Manufacturing of the runner and experiment on the system with nozzle model 3 show that the runner with SS 304 is able to generates larger power to 8,38 Watt,100\% larger than the Aluminium 6061.

Keywords: Renewable Energy; Cross-flow turbine; CFD; CAM 


\section{PENDAHULUAN}

\section{Latar Belakang}

Kebutuhan energi untuk dapat digunakan oleh manusia terus mengalami peningkatan. Namun, pandemi Covid-19 yang terjadi di seluruh dunia mengakibatkan perubahan jumlah energi yang dimanfaatkan. World Enegy Outlook 2020 berdasarkan ringkasan eksekutif melaporkkan bahwa pandemi Covid-19 menyebabkan disrupsi pada sector energi sehingga dapat mempengaruhi transisi energi menuju energu baru dan terbarukan (Executive Summary, 2020). Selama masa pandemi Covid-19, konsumsi energi fosil mengalami penurunan, sedangkan konsumsi energi baru dan terbarukan mengalami kenaikan, seperti yang ditunjukkan oleh gambar (World Energy Outlook 2020, 2020). Fenomena ini menunjukkan bahwa energi terbarukan merupakan sumber energi yang efektif untuk terus dikembangkan. Terlebih pengembangan terhadap energi terbarukan merupakan salah satu goal dari Sustainable Development Goals (SDG's) oleh PBB, yaitu Goal ke 7 (Affordable and clean energy) (UN, 2015). Pembangkit energi bertenaga air merupakan penggerak mula dengan sumber energi terbarukan. Pada lingkup penggunaan skala kecil, sistem pembangkit dengan sumber energi air diklasifikasikan menjadi beberapa jenis, yaitu mikro hidro dan piko hidro untuk daya hingga $15 \mathrm{~kW}$. Jenis sistem pikro hidro ini sesuai untuk digunakan pada area kecil dan tinggi tekan air yang tidak terlalu besar (Riley, 2014; Rossetti et al., 2011).

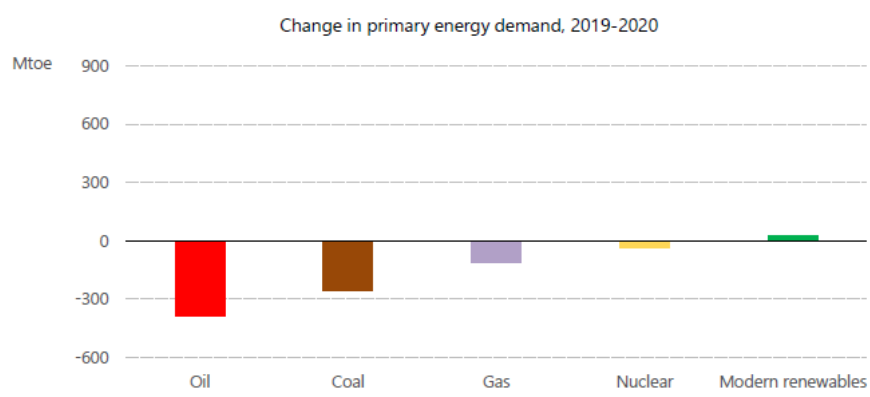

Gambar 1. Penggunaan energi 2019-2020 berdasarkan jenis energi

Turbin cross-flow merupakan turbin radial yang menghasilkan daya melalui konversi energi hidrolik menjadi energi mekanis melalui penggunaan nosel dan runner (Mockmore \& Merryfield, 1949), (S. Darmawan et al., 2015). Turbin cross-flow banyak digunakan karena beberapa kelebihannya, antara lain konstruksi yang sederhana dan simetris hanya memerlukan biaya perawatan yang rendah dan sederhana serta dapat digunakan pada rentang beban yang cukup besar. Secara umum, sistem turbin cross-flow terdiri dari runner dan nosel seperti yang ditunjukkan oleh Gambar 2. Namun demikian, turbin cross-flow secara umum memiliki nilai efisiensi yang lebih rendah apabila dibandingkan dengan turbin hidrolik lainnya. (Pereira \& Borges, 2014), (Yassen, 2014). Beberapa metode yang dapat dilakukan untuk meningkatkan efisiensi turbin ini antara lain dengan melakukan desain nosel yang sesuai dengan rentang operasi turbin. Desain dari nosel menjadi semakin penting karena terjadi perubahan tekanan air menjadi kecepatan yang selanjutnya dialirkan menju runner. Untuk mendapatkan fleksibilitas desain geometri nosel dan sudut bukaan guide vane, metode CFD semakin popular untuk digunakan dalam desain nosel (Acharya et al., 2015), (Sardjono et al., 2020) (Chen \& Choi, 2013). Air dengan kecepatan tinggi yang menumbuk runner menjadikan faktor pemilihan material serta proses manufaktur yang sesuai juga merupakan faktor yang mempengaruhi unjuk kerja sistem. Runner cross-flow dapat dibuat dengan menggunakan berbagai jenis material yang memiliki ketahanan korosi yang tinggi Secara umum, turbin runner padda turbin cross-flow dapat dibuat dengan menggunakan material stainless steel, paduan alunimium hingga plastic ABS. Pada operasinya, momen inersia yang dimiliki oleh material akan dapat mempengaruhi besaran daya yang dapat diekstraksi serta kekuatan dari runner terhadap beban (Kenvarg et al., 2013), (Ni et al., 2016). Pembuatan turbin dapat menggunakan 
berbagai macam cara yaitu dengan buatan tangan, dengan menggunakan proses pemesinan, dan $3 D$ printing. Namun, sesuai dengan aplikasi turbin cross-flow yang spesifik serta kualitas permukaan, metode pemesinan lebih sesuai untuk digunakan (Lubis et al., 2019). Penelitian ini bertujuan untuk melakukan analisis terhadap nosel dan proses manufaktur runner cross-flow sehingga dapat diperoleh kriteria geometri nosel serta jenis material dan proses manufaktur runner yang sesuai untuk rentang operasi yang telah ditetapkan.

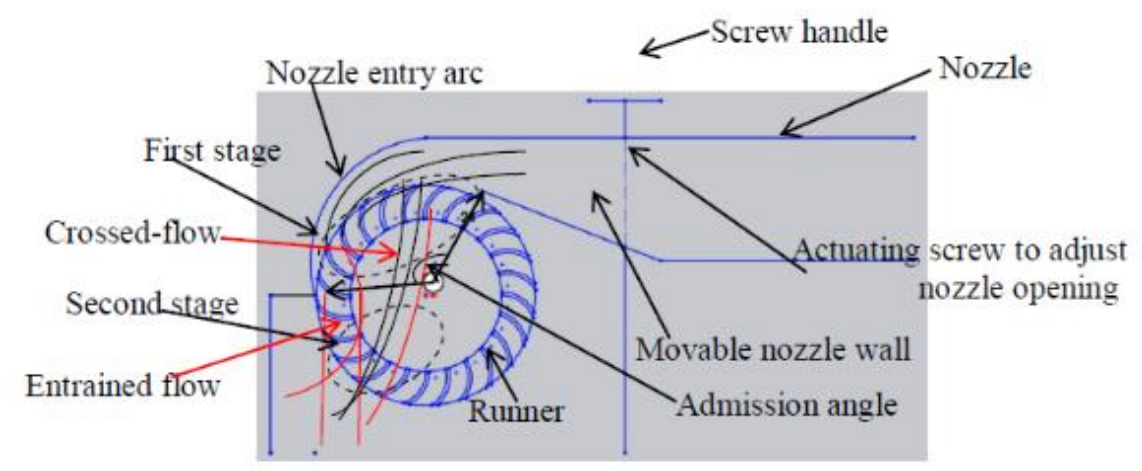

Gambar 2. Sistem turbin cross-flow: runner dan nosel

Sumber: (Kaunda Chiyembekezo S., Kimambo Cuthbert Z., 2014)

\section{METODE PENELITIAN}

Penelitian dilakukan dalam 2 (dua) bagian. Bagian pertama adalah analisis aliran pada nosel secara numerik dengan menggunakan simulasi CFD. Bagian kedua adalah analisis manufaktur runner cross-flow dengan menggunakan metode numerik yaitu simulasi CAM dan eksperimental pada dua jenis material, yaitu SS301 dan Alumnimuin 6061. Parameter desain runner secara umum mengacu kepada (Mockmore \& Merryfield, 1949) yang ditunjukkan oleh Tabel 1.

Tabel 1. Parameter Geometri Runner dan Sistem Turbin Cross Flow

\begin{tabular}{ccc}
\hline No. & Parameter & Nilai \\
\hline 1. & $D$ (diameter luar turbin) & $0,150 \mathrm{~m}$ \\
\hline 2. & $D$ (diameter dalam turbin) & $0,125 \mathrm{~m}$ \\
\hline 3. & Q (Debit air yang digunakan) & $1,4 \mathrm{~L} / \mathrm{s}$ \\
\hline 4. & n (asumsi putaran) & $1000 \mathrm{rpm}$ \\
\hline 5. & Jumlah Sudu & $20 \mathrm{buah}$ \\
\hline 6. & R (jari-jari sudu ) & $0,023 \mathrm{~m}$ \\
\hline
\end{tabular}

\section{Nosel}

Simulasi CFD dilakukan pada 3 buah model geometri seperti yang ditunjukkan pada Gambar 3. Gambar dihasilkan melalui Autodesk Inventor 2018 Educational License dan simulasi CFD dilakukan dengan menggunakan Ansys Workbench 2019 R2 Academic Version. Simulasi CFD dilakukan secara 3 dimensi, keadaan diasumsikan tunak seperti yang ditunjukkan oleh

Tabel 2. Analisis hasil simulasi CFD dilakukan berdasarkan persamaan atur pada persamaan (1) dan persamaan (2) (Munson et al., 2009). Debit 1,4 L/s menghasilkan kecepatan $0.286 \mathrm{~m} / \mathrm{s}$ pada sisi inlet nosel. Intensitas turbulen diasumskan $5 \%$.

Persamaan Bernoulli

$\frac{p}{\gamma}+\frac{V^{2}}{2 g}+z=$ konstan pada arah aliran

Bilangan Reynolds

$R e=\frac{\rho V D}{\mu}$ 


\section{Dengan}

$\begin{array}{ll}p & : \text { Tekanan fluida }\left(\mathrm{N} / \mathrm{m}^{2}\right) \\ \gamma & : \text { Berat jenis fluida }\left(\mathrm{N} / \mathrm{m}^{3}\right) \\ Z & : \text { Ketinggian fluida }(\mathrm{m}) \\ R e & : \text { Bilangan Reynolds } \\ V & : \text { Kecepatan fluida }(\mathrm{m} / \mathrm{s}) \\ D & : \text { Diameter hidrolik }(\mathrm{m}) \\ \mu & : \text { Viskositas dinamik }\left(\mathrm{N} . \mathrm{s} / \mathrm{m}^{2}\right)\end{array}$

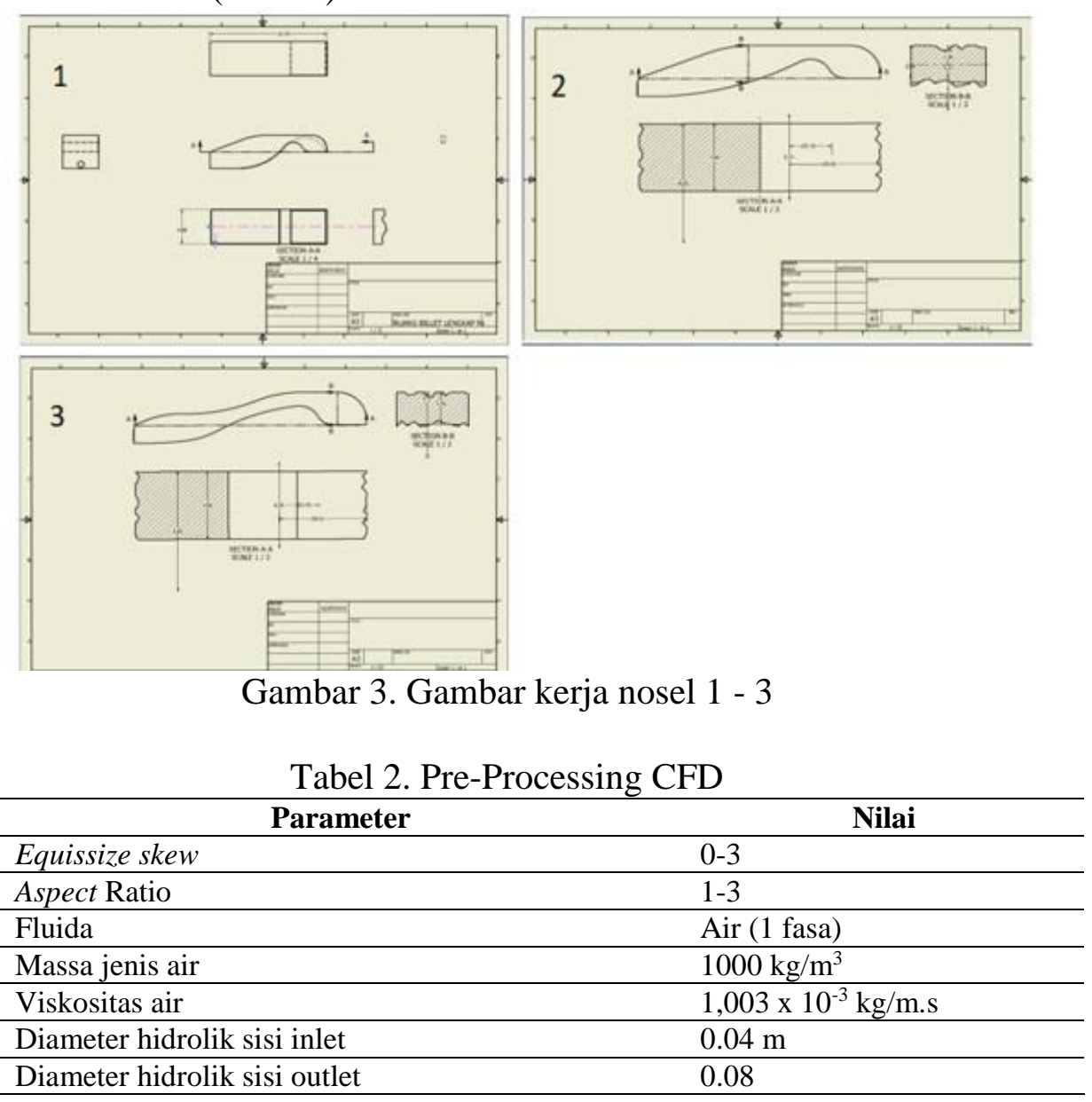

Simulasi CFD dilakukan dengan menggunakan model turbulen STD $k-\varepsilon$ dari Launder \& Spaling (1974) Model ini terdiri dari dua buah persamaan transport, yaitu $k$ dan $\varepsilon$ (Launder $\&$ Spalding, 1974), (Steven Darmawan, 2020).

Persamaan transport $k$ :

$\frac{D k}{D t}=\frac{1}{\rho} \frac{\partial}{\partial x_{k}}\left[\frac{\mu_{T}}{\sigma_{\kappa}} \frac{\partial \kappa}{\partial x_{k}}\right]+\frac{\mu_{T}}{\rho}\left(\frac{\partial U_{i}}{\partial x_{k}}+\frac{\partial U_{k}}{\partial x_{i}}\right) \frac{\partial U_{i}}{\partial x_{k}}-\varepsilon$

Persamaan transport $\varepsilon$ :

$\frac{D \varepsilon}{D t}=\frac{1}{\rho} \frac{\partial}{\partial x_{k}}\left[\frac{\mu_{T}}{\sigma_{\varepsilon}} \frac{\partial \varepsilon}{\partial x_{k}}\right]+\frac{C_{1} \mu_{T}}{\rho} \frac{\varepsilon}{k}\left(\frac{\partial U_{i}}{\partial x_{k}}+\frac{\partial U_{k}}{\partial x_{i}}\right) \frac{\partial U_{i}}{\partial x_{k}}-C_{2} \frac{\varepsilon^{2}}{\kappa}$

\section{Runner Cross-flow}

Manufaktur pada runner cross-flow dilakukan menurut gambar kerja pada Gambar 4 pada dua jenis material berbeda, yaitu Stainless steel 304 dan Aluminium 6061. Kedua jenis material ini dipilih berdasarkan kemudahan proses manufaktur dan ketahanan yang baik terhadap air. Lebih 
jauh, pemilihan kedua jenis material ini sebagai pertimbangan bahwa kedua jenis material ini akan menghasilkan daya yang berbeda karena perbedaan momen inersia yang cukup jauh sesuai dengan properti material yang ditunjukkan oleh Tabel 3. Untuk menghasilkan turbin dengan tingkat presisi yang tinggi, durabilitas yang baik, dan tingkat simetris yang baik maka dipilih pembuatan turbin dengan menggunakan proses pemesinan CNC. Prediksi proses manufkatur dilakukan melalui simulasi CAM pada Autodesk Inventor 2018 Academic Version dengan parameter pemesinan sesuai Tabel 4. Analisis terhadap momen inersia dan unjuk kerja runner diatur menurut persamaan (3) dan (4).

$I=\frac{1}{2} M\left(R_{1}{ }^{2}+R_{2}{ }^{2}\right)$
$E=\frac{1}{2} I \omega^{2}$

Dengan

I : Momen inersia $\left(\mathrm{kg} \cdot \mathrm{m}^{2}\right)$

$M \quad$ : Massa runner $(\mathrm{kg})$

$R_{1} \quad$ : Jari-jari dalam (m)

$R_{2} \quad$ : Jari-jari luar (m)

E : Energi (Joule)

$\omega \quad:$ Kecepatan sudut ( $\mathrm{rad} / \mathrm{s})$

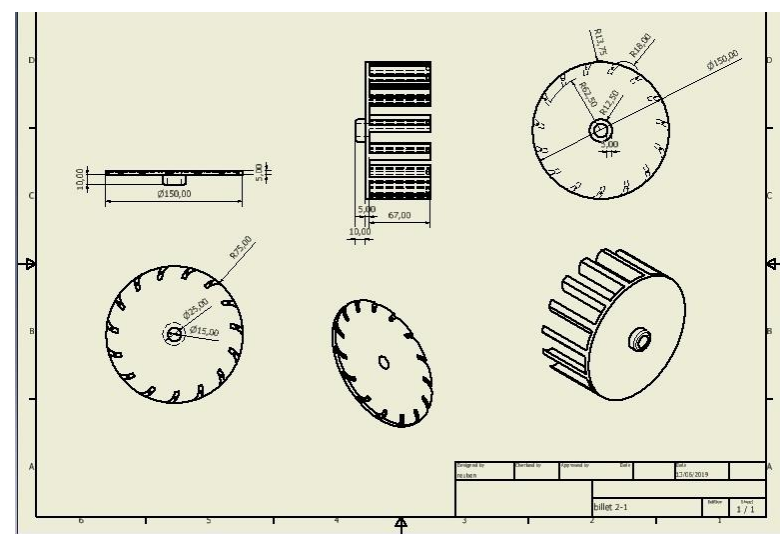

Gambar 4. Gambar kerja turbin cross-flow

Tabel 3. Properti mekanis Stainless Steel 304 dan Aluminium 6061 (Aluminum - Advantages and Properties of Aluminum, n.d.; Stainless Steel - Grade 304 (UNS S30400), n.d.)

\begin{tabular}{lcc}
\hline \multicolumn{1}{c}{ Parameter } & Stainless Steel 304 & Aluminium 6061 \\
\hline Tensile Strength & $510 \mathrm{MPa}$ & $75 \mathrm{MPa}$ \\
\hline Yield Strength & $205 \mathrm{MPa}$ & $30 \mathrm{MPa}$ \\
\hline Density & $7850 \mathrm{~kg} / \mathrm{m}^{3}$ & $2570 \mathrm{~kg} / \mathrm{m}^{3}$ \\
\hline Young's modulus & $190 \mathrm{GPa}$ & $68 \mathrm{MPa}$ \\
\hline
\end{tabular}

Tabel 4. Parameter Pemesinan CAM

\begin{tabular}{cccc}
\hline No. & Parameter & Satuan & Nilai \\
\hline 1. & Spindle speed & $\mathrm{rpm}$ & 5000 \\
\hline 2. & Surface speed & $\mathrm{m} / \mathrm{min}$ & 47.124 \\
\hline 3. & Ramp spindle speed & $\mathrm{rpm}$ & 5000 \\
\hline 4. & Cutting federate & $\mathrm{mm}$ & 800 \\
\hline 5. & Lead-in fedderate & $\mathrm{mm} / \mathrm{rev}$ & 720 \\
\hline 6. & Lead-out fedderate & $\mathrm{mm} / \mathrm{rev}$ & 720 \\
\hline 7. & Ramp federate & $\mathrm{mm} / \mathrm{rev}$ & 720 \\
\hline 8. & Plunge federate & $\mathrm{mm} / \mathrm{min}$ & 30 \\
\hline 9. & Feed per revolution & $\mathrm{mm}$ & 0.006 \\
\hline
\end{tabular}




\section{HASIL DAN PEMBAHASAN}

\section{Simulasi CFD Nosel}

Simulasi CFD secara tiga dimensi telah dilakukan pada 3 buah model geometri dari nosel sesuai Gambar 3. Gambar kerja nosel 1 - 3 Profil aliran pada nosel direprensetasikan melalui 2 (dua) parameter aliran, yaitu kecepatan arah-x dan tekanan. Panjang total 15,75 inch (400mm), lebar 4,88 inch $(124 \mathrm{~mm})$, dan radius pada pengecilan penampang $75 \mathrm{~mm}$.

Dengan kecepatan masuk sebesar 0,286 m/s fluida akan mengalir di sepanjang nosel menuju bagian throat dan keluar menuju turbin yang ditunjukkan oleh Gambar 5. Pada model nosel 1 dan 2 pada kecepatan arah-x, profil kecepatan di sepanjang nosel hingga sisi keluar terus mengalami penurunan, sehingga fenomena peningkatan kecepatan yang diharapkan dapat terjadi pada bagian throat tidak terjadi. Intensitas aliran fluida pada sisi kiri atas dari nosel 1 dan 2 juga sangat rendah sehingga sangat mungkin tidak terjadi aliran pada bagian ini. Fenomena serupa juga ditunjukkan pada kontur tekanan yang ditunjukkan oleh Gambar 6 dimana tekanan fluida akan cenderung turun menuju tekanan lingkungan sesuai dengan persamaan Bernoulli pada persamaan (1). Nosel model 3 menunjukkan hasil yang lebih baik, dengan penyesuaian profil geometri pada sisi kiri atas nosel sehingga fluida lebih terkonsentrasi untuk menuju throat sehingga menghasilkan nilai kecepatan arah-X yang lebih tinggi dibandingkan dengan model nosel 1 dan 2 , yaitu sebesar $0.135 \mathrm{~m} / \mathrm{s}$. Dengan asumsi massa jenis dan viskositas fluida tetap, kecepatan fluida sepanjang nosel cukup banyak terdisipasi, sesuai persamaan (3) dan (4).
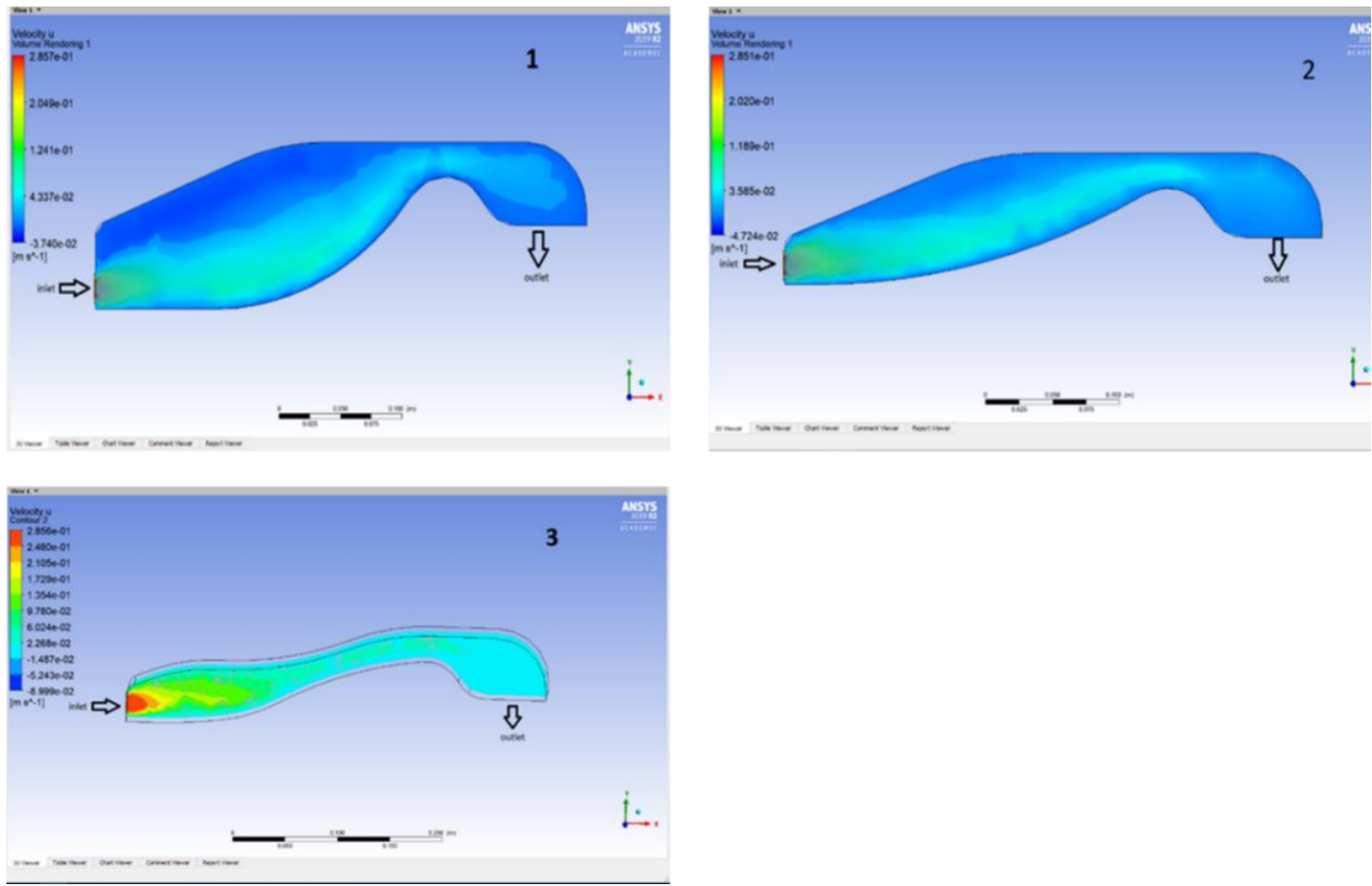

Gambar 5. Kontur kecepatan arah- $x$ sepanjang nosel 

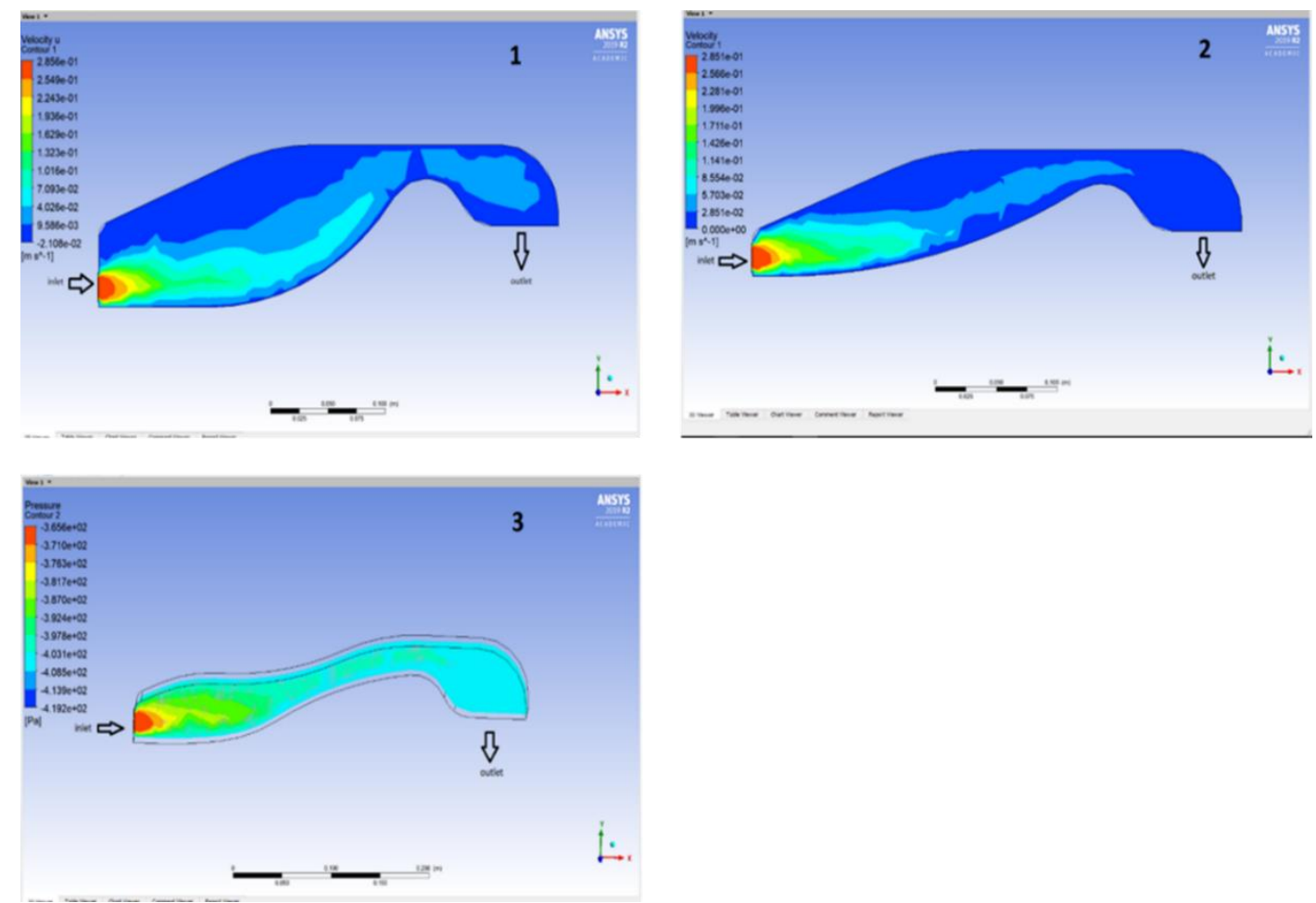

Gambar 6. Kontur tekanan sepanjang nosel

\section{Manufaktur Runner Cross-flow}

Simulasi CAM dan proses pemesinan telah dilakukan pada Runner. Simulasi CAM dilakukan dengan menggunakan Fitur CAM pada Autodesk Inventor 2018 yang ditunjukkan oleh Gambar 7. Dari bongkahan material, baik SS 304 dan Aluminium 6061, proses pemesinan dimulai dengan membuat base plate dan blades sebagai satu kesatuan. Upper plate dibuat pada proses selanjutnya. Hasil simulasi CAM menunjukkan waktu yang dibutuhkan untuk menghasilkan kedua komponen ini adalah 6 jam 28 menit.

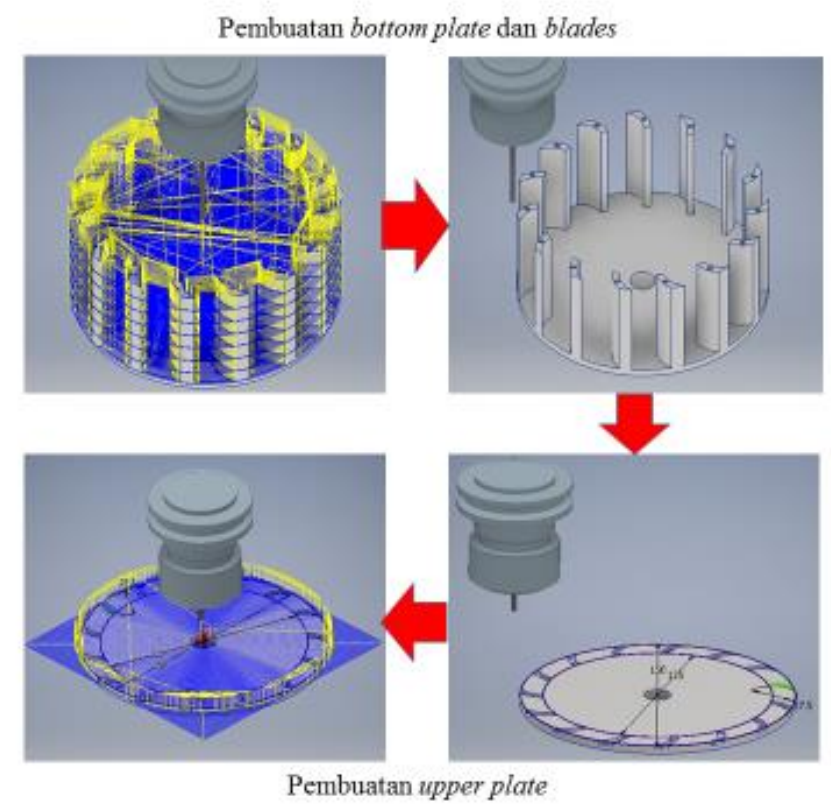

Gambar 7.Simulasi CAM pada runner 


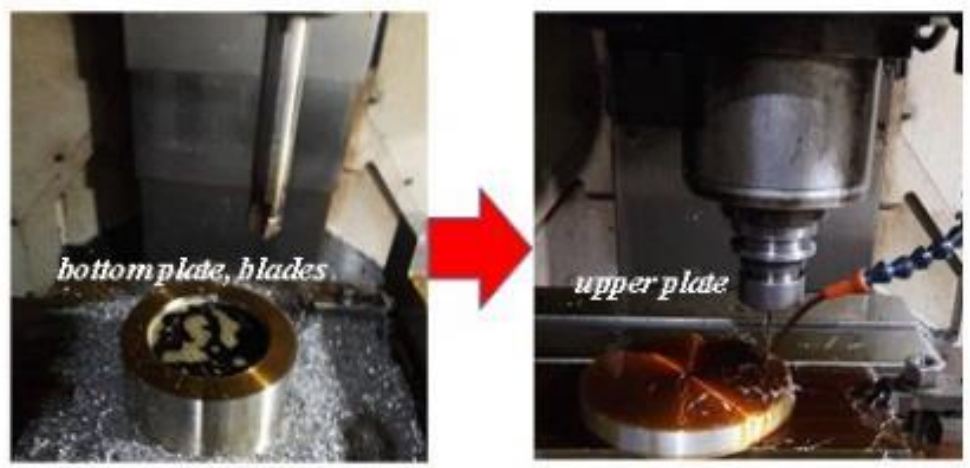

Gambar 8. Proses pemesinan runner menggunakan CNC Milling

Proses pemesinan pada runner dilakukan di workshop dengan menggunakan mesin CNC Milling Serupa dengan simulasi CAM, pembuatan dimulai dari membuang bagian dari bahan yang tidak dibutuhkan, pembuangan dilakukan pertama dengan melubangi bagian tengah sehingga menghasilkan botton plate dan blades menggunakan flat endmill $26 \mathrm{~mm}$, dilanjutkan dengan pembentukan sudu menggunakan flat endmill $3 \mathrm{~mm}$. Pembuatan upper plate menggunakan flat endmill 3mm. Proses pemesinan ini ditunjukkan oleh Gambar 8. Berbeda dengan hasil simulasi, proses pemesinan secara langsung membutuhkan waktu lebih lama, yaitu 8 jam 45 menit. Hasil proses pemesinan runner untuk kedua jenis material ditunjukkan oleh Gambar 9.
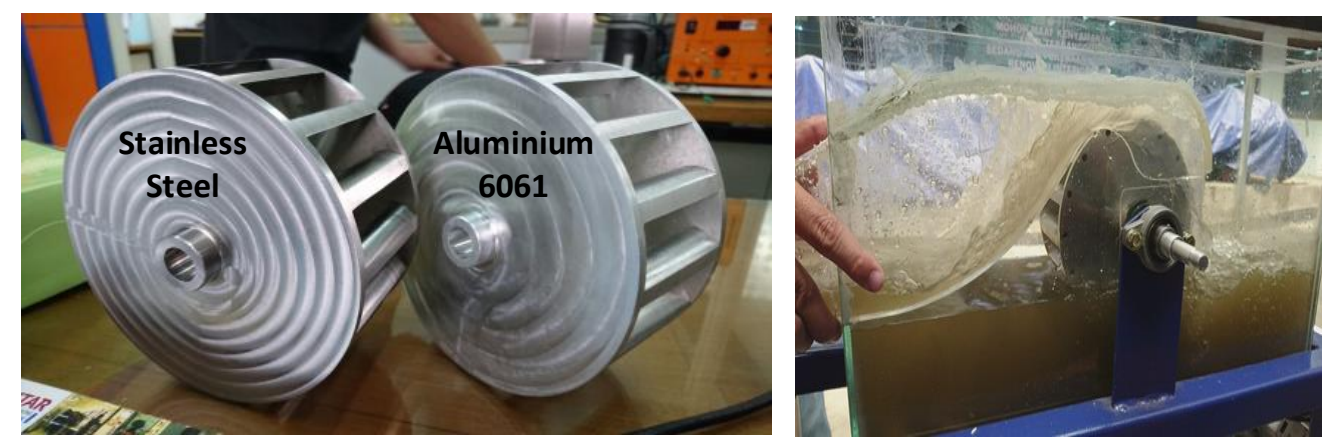

Gambar 9.Hasil manufaktur runner (machining), material SS 304 dan Aluminium 6061 serta eksperimen sistem

\section{Eksperimen terhadap sistem}

Eksperimen awal terhadap sistem turbin cross-flow seperti pada Gambar 9 dilakukan dengan menggunakan konfigurasi nosel yang terpilih dan dengan menggunakan runner cross-flow, baik yang menggunakan material SS 304 dan Aluminium 6061. Nosel tersebut lalu dibuat dengan mengguakan material akrilik. Dengan menggunakan debit aliran air seperti yang yang ditunjukkan oleh Tabel 1.

Tabel 5. Hasil pengujian awal terhadap sistem

\begin{tabular}{cccccc}
\hline Material Runner & $\begin{array}{c}\text { Momen } \\
\text { Inersia, } \boldsymbol{I} \\
\left(\mathbf{k g . m ^ { 2 }}\right)\end{array}$ & $\begin{array}{c}\text { Kecepatan } \\
\text { runner, } \boldsymbol{\omega} \\
(\mathbf{R a d} / \mathbf{s})\end{array}$ & $\begin{array}{c}\text { Tegangan pada } \\
\text { alternator } \boldsymbol{V} \\
(\text { Volt })\end{array}$ & $\begin{array}{c}\text { Energi, } \boldsymbol{E} \\
(\mathbf{J o u l e})\end{array}$ & $\begin{array}{c}\text { Daya, } \boldsymbol{P} \\
(\text { Watt) }\end{array}$ \\
\hline $\mathrm{Al} 6061$ & 0,01315 & 79,546 & 12 & 41,6 & 4,16 \\
\hline SS 304 & 0,03622 & 68,03 & 12 & 83,81 & 8,38 \\
\hline
\end{tabular}

Dari hasil eskperimen, air yang keluar dari nosel tampak langsung menumbuk sudu turbin, bagian atas dari nosel tampak hanya sedikit dialiri oleh air. Hal ini sejalan dengan hasil simulasi CFD pada nosel. Perbaikan terhadap profil ini diharapkan dapat meningkatkan kecepatan air keluar nosel. Dengan massa jenis yang lebih besar, runner dengan material SS 304 memiliki momen 
inersia yang lebih besar dibandingkan dengan runner dengan material Aluminium 6061. Selain mampu menghasilkan momen inersia yang lebih besar, turbin dengan material baja juga cenderung lebih kuat sesuai dengan hasil penelitian (Ni et al., 2016) yang merekomendasikn baja ditinjau dari sisi kekuatan. Namun, dengan konfigurasi nosel dan debit aliran yang sama, runner dengan material Aluminium 6061 mampu menghasilkan putaran poros 79,546 rpm, yang lebih besar dibandingkan dengan SS 304 yaitu 68,03 rpm. Lebih lanjut, Tabel 5 menunjukkan bahwa dengan putaran yang lebih kecil, runner dengan material SS 304 akan menghasilkan daya elektris yang lebih besar, yaitu 8,38 Watt dibandingkan dengan 4,16 Watt pada runner dengan material Al 6061. Tegangan listrik pada alternator diukur dengan rentang waktu 10 detik. Perbedaan nilai daya ini disebabkan karena properti mekanis dari material SS 304 yang memiliki masa jenis lebih besar menurut persamaan (5) dan (6).

\section{KESIMPULAN DAN SARAN}

Hasil simulasi CFD menunjukkan bahwa nosel model 3 dengan dimensi dimensi panjang total 400mm, lebar $124 \mathrm{~mm}$, dan radius pada throat $75 \mathrm{~mm}$ memberikan hasil yang paling baik. Meskipun terjadi penurunan pada sisi outlet menjadi $0.135 \mathrm{~m} / \mathrm{s}$, namun bagian throat menunjukkan pengaruh yang cukup baik sehingga fluida dapat langsung dialirkan menuju runner. Hasil penelitian pada material dan proses manufaktur runner menunjukkan bahwa terdapat perbedaan waktu antara simulasi CAM dengan proses pemesinan aktual, baik pada material SS 304 ataupun Aluminium 6061, yaitu 6 jam 28 menit dan 8 jam 45 menit secara berturut-turut. Eksperimen terhadap sistem dengan nosel model 3 menunjukkan bahwa Runner dengan material SS 304 menghasilkan daya yang lebih besar dibandingkan dengan Aluminium 6061, yaitu 8.38 Watt, $100 \%$ lebih besar dibandingkan dengan runner dengan material Aluminium 6061, yang terutama disebabkan oleh momen inersia runner.

\section{Ucapan Terima Kasih}

Penulis mengucapkan terima kasih kepada Direktorat Penelitian dan Pengabdian kepada Masyarakat Universitas Tarumanagara yang telah memberikan dukungan dana pada penelitian ini sesuai Perjanjian Pelaksanaan Penelitian Nomor: 813-Int.-DIR.PKKM/UNTAR/V/2019.

\section{REFERENSI}

Acharya, N., Kim, C., Thapa, B., \& Lee, Y. (2015). Numerical analysis and performance enhancement of a cross- fl ow hydro turbine *. Renewable Energy, 8-15. https://doi.org/10.1016/j.renene.2015.01.064

Aluminum - Advantages and Properties of Aluminum. (n.d.). Retrieved May 14, 2021, from https://www.azom.com/properties.aspx?ArticleID=1446

Chen, Z. M., \& Choi, Y. D. (2013). Performance and internal flow characteristics of a cross-flow turbine by guide vane angle. IOP Conference Series: Materials Science and Engineering, 52(TOPIC 5). https://doi.org/10.1088/1757-899X/52/5/052031

Darmawan, S., Siswantara, A. I., Budiarso, Daryus, A., Gunawan, A. T., Wijayanto, A. B., \& Tanujaya, H. (2015). Turbulent flow analysis in auxiliary cross-flow runner of a Proto X-3 Bioenergy micro gas turbine using RNG K-E turbulence model. ARPN Journal of Engineering and Applied Sciences, 10(16).

Darmawan, Steven. (2020). Reynolds number effects on swirling flows intensity and reattachment point over a backward-facing step geometry using STD k- $\varepsilon$ turbulence model. IOP Conference Series: Materials Science and Engineering, 852(1). https://doi.org/10.1088/1757-899X/852/1/012073

Executive Summary. (2020). World Energy Outlook 2020. 
Kaunda Chiyembekezo S., Kimambo Cuthbert Z., N. K. (2014). A numerical investigation of flow profile and performance of a low cost Crossflow turbine. International Journal of Engry and Enviroment, 5(3), 275-296.

Kenvarg, A., Rosenberg, J., \& Regulinski, J. (2013). Bike Wheels, Rotational Inertia , and Energy Which of These is Easier to Spin?

Launder, B., \& Spalding, D. B. (1974). The numerical computation of turbulent flows. Computer Methods in Applied Mechanics and Engineering, 3, 270-289.

Lubis, M. S. Y., Siahaan, E., \& Darmawan, S. (2019). Variation Of Cutting Parameters In The Process Of Turning AISI 4340 Steel On Surface Roughness. Sinergi. Sinergi, 23(2), 139144.

Mockmore, C. A., \& Merryfield, F. (1949). The Banki Water Turbine. Bulletin Series, 25. https://doi.org/10.7763/IJMMM.2013.V1.35

Munson, B. R., Young, D. F., Okiishi, T. H., \& Huebsch, W. W. (2009). Fundamentals of Fluid Mechanics. John Wiley \& Sons, Inc.

Ni, Z., Win, T., Htay, H., \& Thein, M. (2016). Performance Test and Structural Analysis of CrossFlow Turbine. American Scientific Research Journal for Engineering, Technology, and Sciences (ASRJETS), 26(4), 285-303.

Pereira, N. H. C., \& Borges, J. E. (2014). Prediction of the Cross-Flow Turbine Efficiency with Experimental Verification. Journal of Hydraulic Engineering, 139(July), 04016035. https://doi.org/10.1061/(ASCE)HY

Riley, P. H. (2014). Affordability for sustainable energy development products. Applied Energy, 132, 308-316. https://doi.org/10.1016/j.apenergy.2014.06.050

Rossetti, A., Ardizzon, G., Santolin, A., Cavazzini, G., \& Pavesi, G. (2011). Techno-economical method for the capacity sizing of a small hydropower plant. Energy Conversion and Management, 52(7), 2533-2541. https://doi.org/10.1016/j.enconman.2011.01.001

Sardjono, J. A., Darmawan, S., \& Tanujaya, H. (2020). Flow investigation of cross-flow turbine using CFD method. IOP Conference Series: Materials Science and Engineering, 1007(1). https://doi.org/10.1088/1757-899X/1007/1/012035

Stainless Steel - Grade 304 (UNS S30400). (n.d.). Retrieved May 14, 2021, from https://www.azom.com/properties.aspx?ArticleID=965

UN. (2015). Sustainable Development Goals. 16301(October), 1-35.

World Energy Outlook 2020. (2020). October.

Yassen, S. R. (2014). Optimization of the Performance of Micro Hydro-Turbines for Electricity Generation Optimization of the Performance of Micro Hydro-Turbines for Electricity Generation. 